\title{
Microorganisms in Small Patterned Ground Features and Adjacent Vegetated Soils along Topographic and Climatic Gradients in the High Arctic, Canada
}

\author{
Grizelle González ${ }^{1}$, Francisco J. Rivera-Figueroa ${ }^{2}$, William A. Gould ${ }^{1}$, \\ Sharon A. Cantrell ${ }^{2}$, José R. Pérez-Jiménez ${ }^{2}$ \\ ${ }^{1}$ International Institute of Tropical Forestry (IITF) USDA, Forest Service, Río Piedras, Puerto Rico; ${ }^{2}$ School of Science and Tech- \\ nology, Universidad del Turabo, Gurabo, Puerto. \\ Email: ggonzalez@fs.fed.us
}

Received December $6^{\text {th }}, 2013$; revised January $6^{\text {th }}, 2014$; accepted January $13^{\text {th }}, 2014$

Copyright (C) 2014 Grizelle González et al. This is an open access article distributed under the Creative Commons Attribution License, which permits unrestricted use, distribution, and reproduction in any medium, provided the original work is properly cited. In accordance of the Creative Commons Attribution License all Copyrights (C) 2014 are reserved for SCIRP and the owner of the intellectual property Grizelle González et al. All Copyright (C) 2014 are guarded by law and by SCIRP as a guardian.

\begin{abstract}
In this study, we determine differences in total biomass of soil microorganisms and community structure (using the most probable number of bacteria (MPN) and the number of fungal genera) in patterned ground features (PGF) and adjacent vegetated soils (AVS) in mesic sites from three High Arctic islands in order to characterize microbial dynamics as affected by cryoturbation, and a broad bioclimatic gradient. We also characterize total biomass of soil microorganisms and the most probable number of bacteria along a topographic gradient within each bioclimatic subzone to evaluate whether differences in topography lead to differences in microbial dynamics at a smaller scale. We found total microbial biomass $\mathrm{C}$, the most probable number of heterotrophic bacteria, and fungal genera vary along this bioclimatic gradient. Microbial biomass $C$ decreased with increasing latitude. Overall, microbial biomass C, MPN and the number of fungal isolates were higher in AVS than in PGFs. The effects which topographic position had on microbial biomass $C$ varied across the bioclimatic gradient as there was no effect of topographic position in Isachsen (subzone A) and Mould Bay (subzone B), when compared to Green Cabin (subzone C, warmer site).There was no effect of topographic position on MPN counts at Mould Bay and Green Cabin. However, in Isachsen, MPN counts were highest in the wet topographic position as compared to the mesic and dry. In conclusion, PGFs seem to decouple the effect climate that might have on the total biomass of soil microorganisms along the bioclimatic gradient; and influence gets ameliorated as latitude increases. Similarly, the effect of topography on the total microbial biomass is significant at the warmest bioclimatic zone of the gradient. Thus, climate and topographic effects on total microbial biomass increase with warmer climate.
\end{abstract}

\section{KEYWORDS}

Soil Microorganisms; High Arctic; Canada; Patterned Features; Microbial Biomass

\section{Introduction}

The Arctic, far from a homogenous biome in terms of ecosystem properties and processes, exhibits a great deal of ecological variation along gradients of climate, substrate, topography, and disturbance [1]. The bioclimatic gradient in the Arctic explains much of the variation in vegetation cover, species diversity and ecosystem patterns $[2,3]$. Within a bioclimatic subzone, the mosaic of vegetation and associated ecosystem properties and processes is controlled at a broad scale by soil chemistry, with strong differences between acidic and nonacidic parent material [4] and at a finer scale by topographic gradients controlling soil moisture, snow depth, exposure, and soil development [5]. Superimposed over these gradients is the pattern developed by the persistent disturbance of cryoturbation or soil churning due to soil water movement and frost heave, which creates patterned 
ground features [6]. While much is known about the general patterns related to this hierarchy of controls, little has been documented on the patterns of belowground microbial communities and activities in and between patterned ground features.

Small patterned-ground features (PGFs) are an ubiquitous and heterogeneous group of landforms that have been extensively described in polar and high alpine environments [7]. PGFs result from intensive and cyclic frost heave action [8] due to the seasonal expansion of ice lenses and the upward movement of unfrozen ground during the annual freeze thaw cycles in permafrost landscapes [6]. Areas dominated by PGFs contain diverse and ecologically complex ecosystems in the Arctic. The center portion of the PGFs is often not vegetated (See Figure 1)-so contributing to the characteristic portrayal of High Arctic ecosystems as large areas of bare groundyet, they are important to global $\mathrm{C}$ budgets because they contain a large reservoir of soil C [9] as organic materials from the adjacent vegetated areas get incorporated into
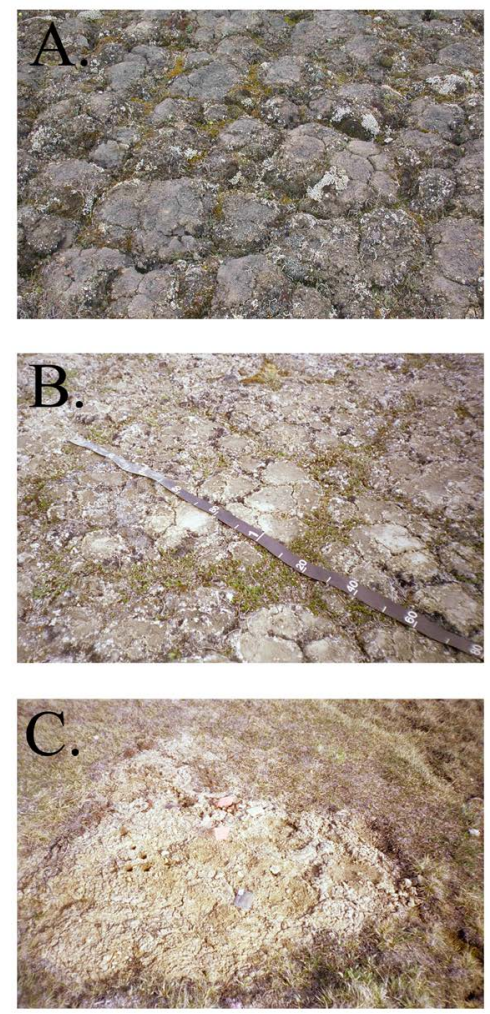

Figure 1. Pattern ground features on mesic (zonal) sites along the bioclimatic gradient. (A) Small polygon features (about $10 \mathrm{~cm}$ diameter) initiated by contraction cracks, surrounded by non woody vegetation in Isachsen in Ellef Rignes Island (subzone A); (B) Small polygon features (10 $20 \mathrm{~cm}$ diameter) with woody vegetation in surrounding cracks at Mould Bay in Prince Patrick Island (subzone B); and (C) Large areas of exposed soil within frost boil ( $>1$ m in diameter) at Green Cabin in Banks Island (subzone $\mathbf{C}$ ). the soil horizons within the PGF during the seasonal freeze-thaw cycles.

High Arctic ecosystems - and PGFs in particular-are vulnerable to climate change as General Circulation Models of the Earth's climate system predict profound changes in the abiotic environment of high-latitude ecosystems [10]. In northern North America, mean summer temperatures are expected to increase $2^{\circ} \mathrm{C}-4^{\circ} \mathrm{C}$, and annual precipitation could increase $20 \%-25 \%$ over all seasons. High temperatures will put soil C stocks at risk of mineralization via increases in microbial respiration [11]; and the potential exists for major shifts in vegetation cover and biomass with the encroachment of plant species into otherwise bare or uncolonized areas of soil [12]. Thus, soil heterotrophic organisms may play an important role in the complex interactions and positive feedbacks among climate change, vegetation and soils within PGFs and adjacent vegetated areas in High Arctic eco-systems.

Numerous scientists have studied aboveground organismal patterns across Arctic latitudinal and topographic gradients [13-15]. In contrast, measurements of microbial biomass and its activity in Arctic ecosystems have been scarce except for a few IBP studies during the 1970s $[16,17]$, as presented by [18] or obtained from toposequences within a bioclimatic zone [19]. Increasing efforts to understand microbial biomass distribution activity are needed to better understand their role of arctic tundra systems in the global carbon cycle [18]. In this study, we determine differences in total biomass of soil microorganisms and community structure (using most probable number of bacteria and the number of fungal genera) in patterned ground features and adjacent vegetated soils in mesic sites from three High Arctic islands in order to characterize microbial dynamics as affected by cryoturbation, and a broad bioclimatic gradient. Within a bioclimatic subzone, different tundra ecosystems have been found to be positioned along topographic gradients in response to soil moisture or nutrient regimes $[13,14]$. In this study, we characterize total biomass of soil microorganisms and the most probable number of bacteria along a topographic gradient within each bioclimatic subzone to evaluate whether differences in topography lead to differences between PGF's and adjacent vegetated soils, and these differences vary along the bioclimatic and topographic gradients. To our knowledge, no previous studies have characterized the biomass of soil microorganisms in PGFs and adjacent vegetated soils in High Arctic ecosystems. The data provided in this study will help in the understanding of how the total biomass of soil microorganisms is distributed at various scales-from bioclimatic to topographic gradients-and how it is affected by cryoturbation (e.g., patterned ground features) in the Canadian High Arctic. 


\section{Methods}

\subsection{Study Sites and Sampling Design}

Three islands located along a High Arctic bioclimate gradient were chosen as study sites; each representing a different bioclimate subzone within the western Canadian Arctic Archipelago (Figure 2). We established study sites in 1) Subzone A at Isachsen on Ellef Ringnes Island, Nunavut $\left(78^{\circ} 47^{\prime} \mathrm{N}, 103^{\circ} 33^{\prime} \mathrm{W}\right)$; 2) Subzone B at Mould Bay on Prince Patrick Island, N.W.T. $\left(76^{\circ} 13^{\prime} \mathrm{N}\right.$, $\left.119^{\circ} 17^{\prime} \mathrm{W}\right)$; and 3) Subzone C at Green Cabin on Banks Island, N.W.T. $\left(73^{\circ} 13^{\prime} \mathrm{N}, 119^{\circ} 33^{\prime} \mathrm{W}\right)$. The subzone classification is based on floristic composition, climate and structure of the vegetation [19]. The sites and bioclimate subzones sampled in this study are described in detail in [19] and [6], and summarized in Table 1. Subzone A is a cushion-forb subzone; characterized by the absence of woody species and sedges and the dominance of herbaceous dicots, grasses, rushes, bryophytes, and lichens [21, 22]. It is equivalent to the Russian polar desert [22] and restricted to the low-lying Queen Elizabeth Islands and northern and westernmost edges of Ellesmere and Axel Hieberg Islands in the North American Arctic. Primary variation in plant species composition within this zone is related to substrate chemistry. Within a given substrate, this variation is related to topographic position and soil moisture and secondarily to patterned ground features $[14,23]$. Soils at our study sites in Subzone A consist of clays derived from the Christopher Formation marine shales [24]. Subzone B is a prostrate dwarf-shrub subzone that is characterized by the presence of Dryas integrifolia and Salix arctica but few other woody species.
The soils around the Mould Bay formed mainly from the Jurassic Wilke Point Formation, which consists of lightgray, very fine grained sands, sandstones and siltstones, and the Devonian Griper Bay Formation, which has light-colored, fine to medium grained sandstones [24]. Subzone $\mathrm{C}$ is a hemi prostrate dwarf shrub subzone which is characterized by the presence of additional woody species, including the hemi prostrate shrub Cassiopetetragona, and increased diversity in sedges and herbaceous species [20]. At this zone, our study sites are composed of well-weathered glacial till deposited during the middle-Pleistocene [25].

At each study site (subzone), we determined zonal vegetation and soils by looking for areas with mesic finegrained soils with typical local vegetation, with no extremes of moisture, slope, soil chemistry or disturbance [26,27]. We set up three $20 \mathrm{~m}$ long transects in this zonal vegetation (each at least $5 \mathrm{~m}$ apart); and within each

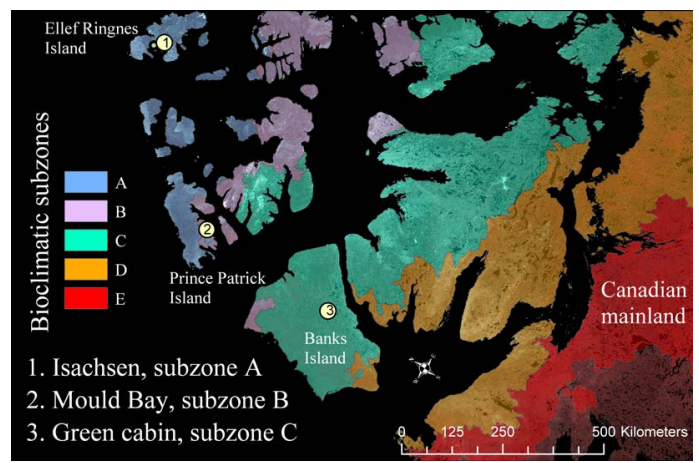

Figure 2. Site locations in subzones $\mathrm{A}, \mathrm{B}$, and $\mathrm{C}$ along the bioclimatic gradient in the Canadian high arctic.

Table 1. Site characteristics including bioclimatic subzone, mean July temperatures (MJT), global extent (area $\left.\times 10^{6} \mathbf{k m}^{2}\right)$, characteristic growth form (Gould et al. 2003), characteristic plant communities (Vonlanthen et al. 2007) on small patterned ground feature (PGF) and adjacent vegetated soils (AVS), and latitude and longitude.

\begin{tabular}{|c|c|c|c|c|c|c|c|}
\hline \multirow{2}{*}{ Site } & \multirow{2}{*}{ Subzone } & \multirow{2}{*}{$\begin{array}{l}\mathrm{MJT} \\
\left({ }^{\circ} \mathrm{C}\right)\end{array}$} & \multirow{2}{*}{$\begin{array}{l}\text { Global } \\
\text { extent }\end{array}$} & \multirow{2}{*}{$\begin{array}{l}\text { Characteristic } \\
\text { growth forms }\end{array}$} & \multicolumn{3}{|c|}{ Characteristic plant communities } \\
\hline & & & & & on PGF & on AVS & Lat. Long. \\
\hline $\begin{array}{l}\text { Isachsen, } \\
\text { Ellef Ringnes } \\
\text { Island, } \\
\text { Nunavut }\end{array}$ & A & $1-3$ & 100 & $\begin{array}{l}\text { cushion-forbs/graminoids/ } \\
\text { mosses/lichens }\end{array}$ & $\begin{array}{l}\text { Puccinellia angustata-Papaver } \\
\text { radicatum comm. (dry and mesic } \\
\text { sites) Polytrichum piliferum- } \\
\text { Pertussaria octomela comm. } \\
\text { (wet sites) }\end{array}$ & $\begin{array}{l}\text { Saxifrago-Parmelia } \\
\text { omphalodes ssp. glacialis comm. } \\
\text { (dry and mesic sites) } \\
\text { Aulacomnium turgidum- } \\
\text { Racomitrium ericoides comm. } \\
\text { (wet sites) }\end{array}$ & $\begin{array}{l}78^{\circ} 47^{\prime} \mathrm{N} \\
103^{\circ} 33^{\prime} \mathrm{W}\end{array}$ \\
\hline $\begin{array}{l}\text { Mould Bay, } \\
\text { Prince } \\
\text { Patrick } \\
\text { Island, } \\
\text { N.W.T. }\end{array}$ & B & $3-5$ & 447 & $\begin{array}{l}\text { Prostrate dwarf shrubs/ } \\
\text { graminoids/mosses/lichens }\end{array}$ & $\begin{array}{l}\text { Hypogymnia subobscura- } \\
\text { Leproloma comm. (dry and } \\
\text { mesic sites) }\end{array}$ & $\begin{array}{l}\text { Orthotrichium speciousum-Salix } \\
\text { arctica comm. (dry sites) Dryas } \\
\text { integrifolia-Luzula nivalis } \\
\text { comm. (mesic sites) }\end{array}$ & $\begin{array}{l}x \\
76^{\circ} 13^{\prime} \mathrm{N} \\
119^{\circ} 17^{\prime} \mathrm{W}\end{array}$ \\
\hline $\begin{array}{l}\text { Green Cabin, } \\
\text { Banks Island, } \\
\text { N.W.T. }\end{array}$ & $\mathrm{C}$ & $5-7$ & 1167 & $\begin{array}{l}\text { prostrate and hemi prostrate } \\
\text { dwarf shrubs/graminoids }\end{array}$ & $\begin{array}{l}\text { Puccinellia angustata-Potentilla } \\
\text { vahliana comm. (dry sites) Dryas } \\
\text { integrifolia-Carex rupestris } \\
\text { comm. Psora decipiens variant } \\
\text { (mesic sites) Braya glabella ssp. } \\
\text { purpurascens-Dryas integrifolia } \\
\text { comm. (wet sites) }\end{array}$ & $\begin{array}{l}\text { Dryas integrifolia-Carex } \\
\text { rupestris comm. Dryas } \\
\text { integrifolia variant (dry and } \\
\text { mesic sites) Dryas integrifolia- } \\
\text { Carex aquatilis comm. (wet } \\
\text { sites) }\end{array}$ & $\begin{array}{l}73^{\circ} 13^{\prime} \mathrm{N} \\
119^{\circ} 33^{\prime} \mathrm{W}\end{array}$ \\
\hline
\end{tabular}


transect we randomly selected five areas each containing a small patterned ground feature (PGF) and adjacent vegetated tundra soils (AVS) for sampling. We also selected three areas (similarly each containing a small patterned ground feature and adjacent vegetated tundra) within a range of topographic conditions, in drier and wetter areas of each island.

The types of patterned ground on zonal sites varied with bioclimate subzone. Patterns in Subzone A were caused by contraction cracks which created small polygons, about $10 \mathrm{~cm}$ diameter. Some of the cracks had been colonized by mosses and lichens, forming a net of vegetation in an otherwise mostly barren landscape. Patterns in Subzone B were caused by small hummocks (about 20 $\mathrm{cm}$ diameter), with differences in the vegetation communities on and between the hummocks. The patterning in Subzone $\mathrm{C}$ was due to differential frost heave, though the patterning was at a larger scale than in Subzone A. Bare areas were about $1 \mathrm{~m}$ diameter, and vegetation covered $>60 \%$ of the area [28] (See Figure 1).

Soils from Subzones B and C were sampled on July 24, 2004, and Subzone A was sampled July 30, 2005. Two soil cored samples ( $1 \mathrm{~cm}$ diameter; 0 - $10 \mathrm{~cm}$ deep) were taken from each of the sampled areas (PGFs and AVS), and mixed to form a composite sample to minimize disturbance to the sites while providing a single, spatially averaged sample sensu [29]. Soils were coarsely sieved $(4.75 \mathrm{~mm})$ to remove rocks and plant material. All microbial measurements were initiated in Puerto Rico within two weeks of the day of collection, during which time soils were kept refrigerated.

\subsection{Microbial Assays}

Soil microbial biomass $C$ was estimated by the substrate induced respiration (SIR) method [30]. The SIR method provides an index of potentially active microbial biomass [29]. For the SIR, we used $10 \mathrm{~g}$ dry mass equivalent of soil samples placed in glass flasks connected to an ER-10 Columbus Instruments respirometer. Amounts of substrate previously determined to induce maximal respiration (4 mg glucose- $C \cdot \mathrm{g}^{-1}$; [31]) were uniformly added to the flasks and soil microbial biomass $\mathrm{C}$ was calculated from the $\mathrm{CO}_{2}$ evolved [32]. SIR was performed on the 30 soil samples, (15 PGFs and 15 AVS) collected from the three transects, located at the zonal (mesic) site, from each of the three islands (90 samples total). In addition, soil samples from 3 PGFs and 3 AVS located at drier and wetter areas were used for SIR determination and for each of the three islands (36 samples total).

Cultivable heterotrophs (bacteria) were obtained using a dilution culture method [33]; where microorganisms were extracted from the soil in $0.1 \%$ sodium pyrophosphate solution (1.0 g wet weight of soil in $9 \mathrm{ml}$ of solu- tion) by shaking vigorously by hand. A serial 10 -fold dilution of the extract was used to inoculate $5 \mathrm{ml}$ test tubes containing tryptic soy broth (five tubes per dilution). The tubes were incubated for 4 weeks at $7^{\circ} \mathrm{C}$ in darkness. Growth of total bacterial heterotrophs was scored by visually checking for turbidity. The most probable number of cells (MPN) was calculated from the number of positive tubes from the five replicates and the last six dilutions $\left(10^{-4}\right.$ to $\left.10^{-9}\right)$, using Special K's MPN Assay Analyzer software program

(http://www.goecities.com/cpsc319/). MPN were performed on soil samples from 3 PGFs and 3 AVS located at the dry, mesic and wet areas in each of the three islands (18 samples per island, 54 total).

Fungal isolates were obtained from soil samples from 3 PGFs and 3 AVS located at the mesic areas in each of the three islands (6 samples per island, 18 total). The isolates were obtained from a series of dilutions of 1 to 100 dilutions ( $1 \mathrm{~g}$ wet weight of soil in $99 \mathrm{ml}$ solution) followed by 1 to 1000 using the same extracting solution as bacterial cultures. About $10 \mathrm{ml}$ of each dilution was filtered through a $0.42 \mu \mathrm{m}$ filter membrande. This process was repeated two times in other to produce two sets membranes-one of the membranes was placed on sabouraud dextrose agar and the other on rose bengal agar plates; in order to amplify the possibility of isolates using different substrate mediums. The membranes were incubated two weeks at $7^{\circ} \mathrm{C}$. Fungal colonies were counted and isolated in potato dextrose agar for identification using morphological features of their fruiting bodies.

\subsection{Statistical Analysis}

All statistical analysis were performed using the software SPSS (SPSS 11.5, Win 2000). The significance level was set at $\alpha=0.05$. Data were tested for homogeneity of variance by using Levene's test of equality of error variances, and skewness. Two-way analysis of variance (ANOVA) were employed to determine the effect of study site (Green Cabin, Mould Bay and Isachsen), and location (PGF vs. AVS) on microbial biomass C, MPN and FI using the general linear model (GLM) procedure. When significant differences were found for the effect of study site, Student-Newman-Keuls (SNK) tests were used to compare site means for the above mentioned dependent variables. Similarly, we evaluated the effect of topographic position (dry, mesic and wet) on microbial biomass $\mathrm{C}$ and MPN within each of the study sites using ANOVAs. A multivariate analysis of variance (MANOVA) was performed to look at the effects of study site and location (independent variables) on the mean number of the individual and total fungal genera (dependent variables); using SNK post hoc tests for the effect of study site. 


\section{Results}

\subsection{Total Microbial Biomass (SIR)}

Among the mesic (zonal) sites, there was a significant effect of study site (island) and location (PGF vs. AVS) on microbial biomass $C$ using the SIR $\left(R^{2}=0.57\right.$, Power $>0.99, \mathrm{P}<0.05)$. The Green Cabin site at Banks Island had the highest overall microbial biomass (0.36 \pm $0.30 \mathrm{mg} \cdot \mathrm{C} \cdot \mathrm{g}^{-1}$ of dry soil), followed by Mould Bay $(0.27$ $\pm 0.16 \mathrm{mg} \cdot \mathrm{g}^{-1}$ of dry soil) and Isachsen $(0.15 \pm 0.10$ $\mathrm{mg} \cdot \mathrm{C} \cdot \mathrm{g}^{-1}$ of dry soil) when PGF and AVS data was combined $(\mathrm{F}=14.04, \mathrm{P}<0.001)$. Overall, microbial biomass $\mathrm{C}$ was higher in AVS than in PGFs $(\mathrm{F}=42.98, \mathrm{P}<$ 0.001). However, when the effect of location (PGF vs. AVS) was analyzed separately for each of the islands, there was no significant difference in the microbial biomass C between the PGF and AVS in Isachsen at EllefRignes Island in the mesic (zonal) topographic position $\left(\mathrm{F}=0.034, \mathrm{P}=0.85, \mathrm{R}^{2}<0.01\right)$. Microbial biomass $\mathrm{C}$ was significantly higher in AVS than in PGFs at Mould Bay $\left(F=5.64, P=0.02, R^{2}=0.17\right)$, and Green Cabin $(F$ $=51.93, \mathrm{P}<0.0001, \mathrm{R}^{2}=0.65$ ) in the mesic (zonal) topographic position.

When we evaluated the effect of topographic positions (dry, mesic and wet) on microbial biomass C (SIR) within each of the study sites, we found that only at Green Cabin, there was a significant effect of topographic position on microbial biomass $\mathrm{C}\left(\mathrm{P}=0.02, \mathrm{R}^{2}=0.72\right)$. Microbial biomass $\mathrm{C}$ was highest in the dry topographic position and the lowest in the wet topographic position in Green Cabin (Figure 3(C)). Soils collected from the vegetated soils in the dry topographic position in Green Cabin had the highest microbial biomass (Figure 3(C), $0.89 \pm 0.18 \mathrm{mg} \cdot \mathrm{C} \cdot \mathrm{g}^{-1}$ of dry soil). When we analyzed the data from all topographic positions and locations together within a study site, we found that microbial biomass C was significantly higher at AVS than in PGFs at Isachsen $\left(P=0.05, \mathrm{R}^{2}=0.46\right)$ and Green Cabin but not at Mould Bay $\left(P=0.30, \mathrm{R}^{2}=0.34\right)$.

\subsection{Bacterial Population Density (MPN)}

There was a significant effect of study site (island) and location (PGF vs. AVS) on heterotrophic bacterial MPN counts at the mesic (zonal) topographic position $\left(\mathrm{R}^{2}=\right.$ $0.37, \mathrm{P}<0.02)$. MPN counts were highest at Isachsen. MPN counts in Green Cabin showed intermediate values of MPN counts that were not significantly different from those in Mould Bay (SNK, $\alpha>0.05$, Figure 4). Bacterial MPN counts were higher in AVS than in PGFs at all sites ( $\mathrm{F}=16.79, P<0.001$, Figure 4).

We evaluated the effect of topographic position (dry, mesic and wet) on MPN counts within each island and found there was no effect of topographic position on

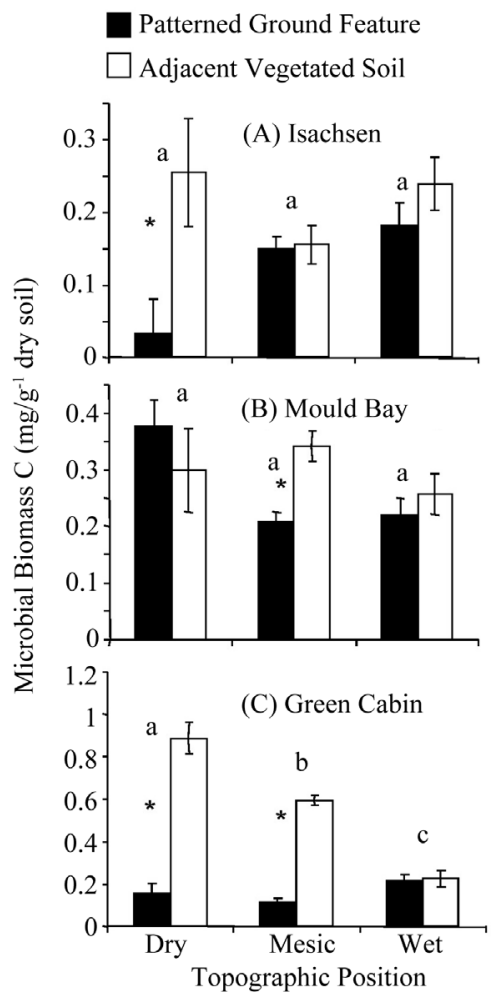

Figure 3. Total microbial biomass (SIR) (mean \pm SE; $\mathbf{n}=3$ ) in PGFs and AVS within a range of topographic positions, in dry, mesic (zonal) and wet areas at (A) Isachsen on Ellef Ringnes Island (Subzone A), (B) Mould Bay on Prince Patrick Island (Subzone B), and (C) Green Cabin on Banks Island (Subzone $\mathrm{C}$ ). Asterisks indicate significant differences between patterned ground feature and adjacent vegetated soils within each topographic position and island. Different letters indicate significant differences among topographic positions within an island. (one-way ANOVAs; $\alpha=$ 0.05).

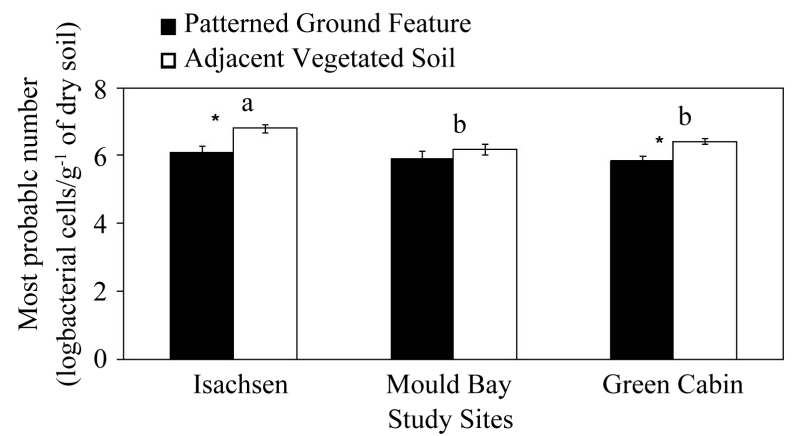

Figure 4. Most probable number (MPN) of bacterial cells (mean \pm SE, $n=18$ ) in PGFs and AVS in the mesic (zonal) locations at Isachsen on Ellef Ringnes Island (Subzone A), Mould Bay on Prince Patrick Island (Subzone B), and Green Cabin on Banks Island (Subzone C). Different letters indicate significant differences among study sites. Asterisks indicate significant differences between patterned ground feature and adjacent vegetated soils within each topographic position and island (one-way ANOVAs; $\alpha=0.05$ ). 
MPN counts at Mould Bay $(\mathrm{F}=2.24, \mathrm{P}=0.15)$ and Green Cabin $(F=3.42, P=0.07)$. However, in Isachsen, MPN counts were highest in the wet topographic position as compared to the mesic and dry $(\mathrm{F}=7.52, \mathrm{P}<0.001$, $\mathrm{R}^{2}=0.70$ ), and MPN counts were significantly higher in AVS than in PGFs in the mesic and wet topographic position at this site. When we pooled the data from all islands, MPN counts show significant differences among the topographical position $(\mathrm{P}=0.04)$ and between PGF and AVS $(P=0.004)$ but no differences among the islands $(\mathrm{P}=0.62)$ sampled $\left(\mathrm{AOV}, \mathrm{R}^{2}=0.52\right)$.

\subsection{Fungal Isolates}

A total of 358 isolates were obtained from all sites. We identified 7 genera and one common Mycelia sterilia (Figure 5). Mycelia sterilia are unidentifiable fungi not producing sexual or asexual spores under culture conditions. Most genera are found on both PGF and AVS. The majority of the isolates belong to Aspergillus, Mucor and Penicillium. At Isachsen, the prevalence of the above three genera demonstrate that they are psychrotolerant, because of the production of abundant conidia and resistant propagules.

Overall, there was no significant effect of site $(\mathrm{F}=$
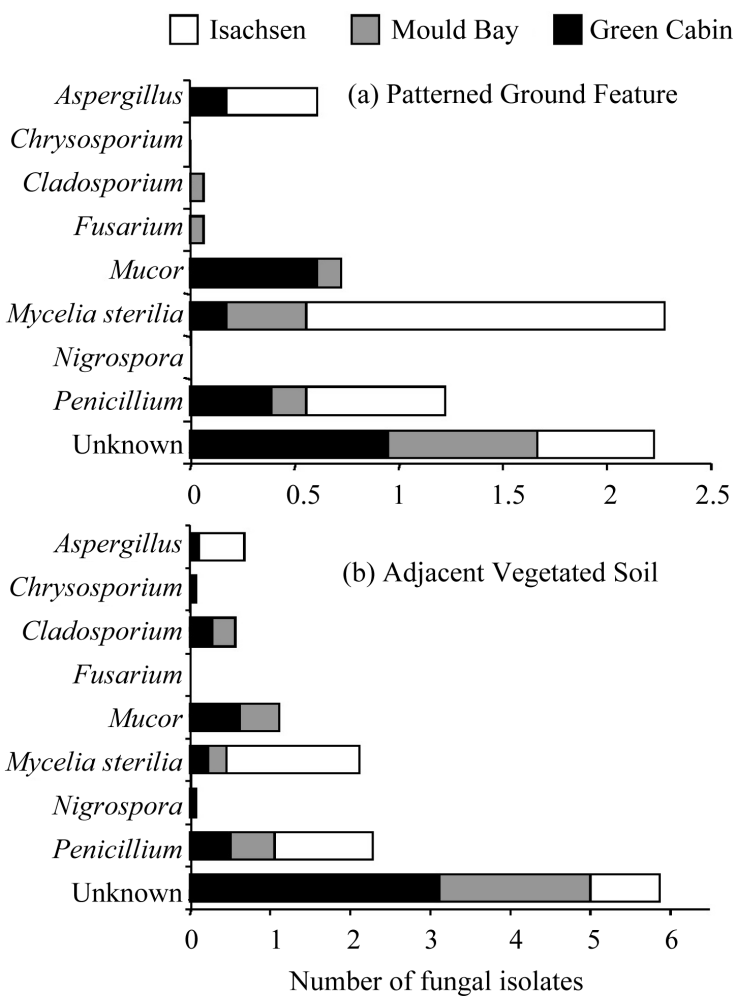

Figure 5. Mean number of fungal genera $(n=18)$ found in PGFs and AVS at Isachsen on Ellef Ringnes Island (Subzone A), Mould Bay on Prince Patrick Island (Subzone B), and Green Cabin on Banks Island (Subzone $\mathrm{C}$ ).
$0.73, P=0.49)$ or location (PGF vs. AVS) $(\mathrm{F}=1.23, P=$ 0.27 ) on the mean total number of fungal isolates; but individual genera varied among sites. Aspergillus (SNK, $\mathrm{F}=10.06, P<0.01$ ) and the Mycelia sterilia (SNK, $\mathrm{F}=$ 14.74, $\mathrm{P}<0.01$ ) were more abundant at Isachsen than at Green Cabin and Mould Bay. Mucor was more abundant at Green Cabin, intermediate at Mould Bay and lowest at Isachsen (SNK, $267 \mathrm{~F}=9.81, P<0.01$, see Figure 5).

\section{Discussion}

The bioclimate zonation in the Arctic has been described in relationship to mean July temperature (MJT) and the dominant plant growth forms and communities [19]. Reference [19] reported that species diversity and biomass of the vegetation, and the horizontal and vertical structure of the plant canopy varied along the bioclimate gradient in predictable ways. In this study, we found that the mean biomass $\mathrm{C}$ of the total soil microorganisms in zonal (mesic) sites also shows predictable patterns among the bioclimate sub-zonation $\mathrm{A}$ to $\mathrm{C}$ within the Canadian High Arctic. We found that microbial biomass $\mathrm{C}$ decreased with increasing latitude from Subzone $\mathrm{C}$ to A.

Reference [34] claimed ecological patterns found in northern Canada are the most complex of the circumpolar Arctic given that this region is a matrix of varying size islands and open and frozen ocean, which greatly affect climatic patterns. Within a climatic regime and substrate type, topographic variation and its effect on soil moisture have been found to control the biogeochemical cycling of nutrients and the dominant patterns of vegetation communities on Arctic landscapes [22,23,35,36]. Reference [37] explained that topographic variation in plant litter biochemistry and soil drainage can shape the metabolic capability of soil microbial communities in northern (low Arctic) Alaska. Given our results, we support that argument as there was a significant effect of topographic position on the microbial biomass $\mathrm{C}$ at the Green Cabin site. However, we argue that the effects which topographic position have on microbial biomass $\mathrm{C}$ vary across the bioclimatic gradient in the Canadian High Arctic as there was no effect of topographic positioning Isachsen (subzone A) and Mould Bay (subzone B), when compared to Green Cabin (subzone C).

Arctic ecosystems are controlled by various factors and due to the complexity inherent to these systems, it has been claimed necessary to encode their detailed characteristics at small scales $[38,39]$. Small patterned ground features could be considered part of the microtopographic variation within a site. Results from this study support the contention that micro-topographic variation within a site can affect soil microorganisms; as we found significant differences in total microbial C (see 
Figure 3), the number of heterotrophic bacteria (See Figure 4), and the number of fungal isolates (see Figure 5 ), in small patterned ground features as compared to adjacent vegetation tundra soils at the mesic (zonal) topographic position.

Although we found significant differences in microbial biomass $\mathrm{C}$ in PGF vs. AVS in the mesic topographic position at Mould Bay and the dry topographic position in Isachsen; overall there is no effect of topographic position at these two sites. By contrast, a significant topographic effect on microbial biomass $\mathrm{C}$ was found at Green Cabin. These results might suggest that the hierarchy of controls which topography and small patterned ground features have on the total biomass of soil microorganisms changes within the bioclimatic gradient. The effect of patterned ground features might be more important at Green Cabin and Mould Bay (subzones C and $\mathrm{B}$, respectively) yet topographic position seem to override the effect of location (PGF vs. AVS) at the Green Cabin site. Further supporting this argument is the finding that the highest microbial biomass $\mathrm{C}$ was in the dry topographic position at Green Cabin.

In this study, we found that at Isachsen, the higher bacterial counts are in the wet topographic position. This finding of increasing microbial counts in wet topographic positions as compared to mesic (zonal) sites is similar to that reported for Barrow, Alaska by [40]; which showed a relative increase in bacteria at wet micro-sites. Wet topographic positions are more favorable conditions for bacteria due to higher carbon contents in the water-saturated layers above the permafrost tables (as it has been shown by others and presented by [41].

The species of fungi most frequently isolated in this study were those of Cladosporium, Penicillium, Мисоrand Aspergillus. According to [42], microorganisms associated with decay of organic matter in tundra soils belong to taxonomic groups which are common in other biomes, but the diversity and the biomass are generally lower. Here we found that some of the fungal genera isolated from these three islands are also common to subtropical regions. In polar environments, fungi are considered to be the most important group involved in cellulose decomposition. Between $50 \%-60 \%$ of carbon in litter can be converted to $\mathrm{CO}_{2}$ by fungal respiration [43]. Overall, in this study, the abundance of fungi was higher in AVS than in PGFs. Plant roots tended to grow in the cracks formed at the interface of AVS and PGFs; and allowing the AVS location to become a repository site for organic material and ultimately a reservoir for fungi. Fungi can establish important symbiotic relationships with the plant community in Arctic environments. In addition, well vegetated tundra soils can provide moisture and nutrient resources (soil organic matter) suitable for fungal development. Although here we found individual fungal genera varying among islands, overall the mean number of total fungal isolates did not differ along the bioclimatic gradient. Similarly, [41] have shown great abundances of fungal biomass in the rooting horizons of tundra soils along an Arctic transect from Tamyr Peninsula in central Siberia; but no relationship of fungi with the composition of the vegetation cover was observed. No differences in the mean total number of fungal isolates among islands could also be explained by the methodology used in this study; as culturing isolates a small percentage of the overall community.

\section{Conclusion}

Total microbial biomass C, the most probable number of heterotrophic bacteria and fungal genera vary along the bioclimatic gradient in the High Arctic Islands in Canada. Differences in soil microbial biomass due to the bioclimatic gradient are evident when comparing vegetated areas among the islands and not in pattern ground features. Disturbance by cryoturbation within small patterned ground features seem to decouple the effect climate might have as an important driver of the total biomass of soil microorganisms along the bioclimatic gradient. Small patterned ground features can reduce the total biomass of soil microorganisms; yet the difference between PGFs and AVS gets ameliorated as latitude increases. Similarly, the effect of topography on the total microbial biomass is significant at the warmest bioclimatic zone of the gradient. Thus, climate and topographic effects on total microbial biomass increase with warmer climate.

\section{Acknowledgements}

We would like to thank Marcela Zalamea, Maria M. Rivera, Verónica Cruz, and Lisabeth Duval for their help. This research was supported by US National Science Foundation (NSF), Office of Polar Programs. Logistical support for the field operations were supplied by VECO Polar Resources, Inc. and the Aurora Institute in Inuvik. We thank the people of Sachs Harbor, who provided logistical help. Additional support was provided from the NSF to the Institute of Tropical Ecosystem Studies (IEET), University of Puerto Rico (UPR), and IITFForest Service (FS; US Department of Agriculture) as part of the Long-Term Ecological Research Program at the Luquillo Experimental Forest. Support for the ABI 3130 Genetic Analyzer was provided by the NSF Major Research Instrumentation program to the Universidad delTurabo. Additional support was provided by the FS and done in cooperation with UPR. We thank Dr. Ariel E. Lugo, and two anonymous reviewers for kindly com- 
menting on earlier versions of the manuscript.

\section{REFERENCES}

[1] D. A. Walker and D. M. Walker, "History and Pattern of Disturbance in Alaskan Arctic Terrestrial Ecosystems: A Hierarchical Approach to Analyzing Landscape Change,” Journal of Applied Ecology, Vol. 28, 1991, pp. 244-276. http://dx.doi.org/10.2307/2404128

[2] P. J. Webber, “Tundra Primary Productivity,” In: J. D. Ives and R. G. Barry, Eds., Arctic and Alpine Environments, Methuen, London, 1974, pp. 445-474.

[3] T. G. Gilmanov and W. C. Oechel, "New Estimates of Organic Matter Reserves and Net Primary Productivity of North American Tundra Ecosystems," Journal of Biogeography, Vol. 22, 1995, pp. 723-741. http://dx.doi.org/10.2307/2845975

[4] D. A. Walker, N. A. Auerbach, J. G. Bockheim, F. S. Chapin III, W. Eugster, J. Y. King, J. P. McFadden, G. J. Michaelson, F. E. Nelson, W. C. Oechel, C. L. Ping, W. S. Reeburg, S. Regli, N. I. Shiklomanov and G. L. Vourlitis, "Energy and Trace-Gas Fluxes across a Soil pH Boundary in the Arctic,” Nature, Vol. 394, 1998, pp. 469-472. http://dx.doi.org/10.1038/28839

[5] K. L. Young, W. Ming-ko and S. A. Edlund, "Influence of Local Topography, Soils, and Vegetation on Microclimate and Hydrology at a High Arctic Site, Ellesmere Island, Canada," Arctic and Alpine Research, Vol. 29, No. 3, 1997, pp. 270-284. http://dx.doi.org/10.2307/1552141

[6] D. A. Walker, H. E. Epstein, V. E. Romanovsky, C. L. Ping, G. J. Michaelson, R. P. Daanen, Y. Shur, R. A. Peterson, W. B. Krantz, M. K. Raynolds, W. A. Gould, G. González, D. J. Nicolsky, C. M. Vonlanthen, A. N. Kade, P. Kuss, A. M. Kelley, C. A. Munger, C. T. Tarnocai, N. V. Matveyeva and F. J. A. Daniëls, "Arctic PatternedGround Ecosystems: A Synthesis of Field Studies and Models along a North American Arctic Transect," Journal of Geophysical Research, Vol. 113, No. G3, 2008, Article ID: G03S01. http://dx.doi.org/10.1029/2007JG000504

[7] C. Tarnocai and S. C. Zoltai, "Earth Hummocks of the Canadian Arctic and Subarctic," Arctic and Alpine Research, Vol. 10, 1978, pp. 581-594. http://dx.doi.org/10.2307/1550681

[8] M. A. Kessler and B. T. Werner, "Self-Organization of Sorted Patterned Ground,” Science, Vol. 299, No. 5605, 2003, pp. 380-383. http://dx.doi.org/10.1126/science.1077309

[9] W. M. Post, W. R. Emanuel, P. J. Zinke and A. G. Stangenberger, "Soil Carbon Pools and World Life Zones," Nature, Vol. 298, 1982, pp. 156-159. http://dx.doi.org/10.1038/298156a0

[10] H. Cattle and J. Crossley, "Modeling Arctic Climate Change," Philosophical Transactions of the Royal Society of London A, Vol. 352, No. 1699, 1995, pp. 201-213. http://dx.doi.org/10.1098/rsta.1995.0064

[11] Y. Bekku, T. Nakatsubo, A. Kume, M. Adachi and H. Koizumi, "Effects of Warming on the Temperature De- pendence of Soil Respiration Rate in Arctic, Temperate and Tropical Soils,” Applied Soil Ecology, Vol. 22, No. 3, 2003, pp. 205-210.

http://dx.doi.org/10.1016/S0929-1393(02)00158-0

[12] C. H. Robinson, P. A. Wookey, J. A. Lee, T. V. Callaghan and M. C. Press, "Plant Community Responses to Simulated Environmental Change at a High Arctic Polar Semi-Desert,” Ecology, Vol. 79, No. 3, 1998, pp. 856-866. http://dx.doi.org/10.1890/0012-9658(1998)079[0856:PCR TSE]2.0.CO;2

[13] W. D. Billings, “Arctic and Alpine Vegetation: Similarities, Differences, and Susceptibility to Disturbance,” BioScience, Vol. 23, 1973, pp. 697-704. http://dx.doi.org/10.2307/1296827

[14] L. C. Bliss, “Arctic Tundra and Polar Desert Biome,” In: M. G. Barbour and W. D. Billings, Eds., North American Terrestrial Vegetation, 2nd Edition, Cambridge University Press, Cambridge, 2000, pp. 1-40.

[15] S. F. Oberbauer, C. E. Tweedie, J. M. Welker, J. T. Fahnestock, G. H. R. Henry, P. J. Webber, R. D. Hollister, M. D. Walker, A. Kuchy, E. Elmore and G. Starr, "Tundra $\mathrm{CO}_{2}$ Fluxes in Response to Experimental Warming across Latitudinal and Moisture Gradients," Ecological Monographs, Vol. 77, No. 2, 2007, pp. 221-228.

http://dx.doi.org/10.1890/06-0649

[16] A. J. Holding, V. G. Collins, D. D. French, B. T. D’Sylva and J. H. Baker, "Relationship between Viable Bacterial Counts and Site Characteristic in Tundra," In: A. J. Holding, O. W. Heal, S. F. MacLean Jr. and P. W. Flanagan, Eds., Soil Organisms and Decomposition in Tundra, Proceedings of the Microbiology, Decomposition, and Invertebrate Working Groups Meeting, Stockholm, 1974, pp. 49-64.

[17] O. K. Miller and G. A. Laursen, "Belowground Fungal Biomass on U.S. Tundra Biome site at Barrow, Alaska," In: A. J. Holding, O. W. Heal, S. F. MacLean Jr. and P. W. Flanagan, Eds., Soil Organisms and Decomposition in Tundra, Proceedings of the Microbiology, Decomposition, and Invertebrate Working Groups Meeting, Stockholm, 1974, pp. 151-158.

[18] W. Cheng and R. A. Virginia, "Measurement of Microbial Biomass in Arctic Tundra Soils Using Fumigation-Extraction and Substrate-Induced Respiration Procedures," Soil Biology and Biochemistry, Vol. 25, No. 1, 1993, pp. 135-141. http://dx.doi.org/10.1016/0038-0717(93)90251-6

[19] D. A. Walker, M. K. Raynolds, F. J. Daniëls, E. Einarsson, A. Elvebakk, W. A. Gould, A. E. Katenin, S. S. Kholod, C. J. Markon, E. S. Melnikov, N. G. Moskalenko, S. S. Talbot and B. A. Yurtsev, "The Circumpolar Arctic Vegetation Map,” Journal of Vegetation, 2005.

[20] W. A. Gould, S. Edlund, S. Zoltai, M. D. Raynolds, D. A. Walker and H. Maier, "Canadian Arctic Vegetation Mapping,” International Journal of Remote Sensing, Vol. 23, No. 21, 2002, pp. 4597-4609. http://dx.doi.org/10.1080/01431160110113962

[21] W. A. Gould, M. Raynolds and D. A. Walker, "Vegetation, Plant Biomass, and Net Primary Productivity Patterns in the Canadian Arctic,” Journal of Geophysical 
Research, Vol. 108, No. D2, 2003, p. 8167. http://dx.doi.org/10.1029/2001JD000948

[22] Y. I. Chernov and N. V. Matveyeva, “Arctic Ecosystems in Russia,” In: F. E. Wielgolaski, Ed., Ecosystems of the World 3: Polar and Alpine Tundra, Elsevier, Amsterdam, 1997, pp. 361-507.

[23] L. C. Bliss and N. V. Matveyeva, "Circumpolar Arctic Vegetation,” In: F. S. Chapin III, R. L. Jeffries, J. F. Reynolds, G. R. Shaver and J. Svoboda, Eds., Arctic Ecosystems in a Changing Environment: An Ecophysiological Perspective, Academic Press, Inc., San Diego, 1992, pp. 59-89. http://dx.doi.org/10.1016/B978-0-12-168250-7.50010-9

[24] K. R. Everett, "Soil Development in the Mould Bay and Isachsen Areas, Queen Elizabeth Islands, N.W.T., Canada," Institute of Polar Studies, Ohio State University, 1968, 75 p.

[25] D. A. Walker, M. K. Raynolds, F. J. Daniëls, E. Einarsson, A. Elvebakk, W. A. Gould, A. E. Katenin, S. S. Kholod, C. J. Markon, E. S. Melnikov, N. G. Moskalenko, S. S. Talbot and B. A. Yurtsev, "The Circumpolar Arctic Vegetation Map,” Journal of Vegetation Science, Vol. 16, 2005, pp. 267-282.

[26] V. B. Sochava, "Botanical-Geographical Subzones in the Western Tundras of Yakutia,” Botanchisky Zhurnal, Vol. 19, 1934.

[27] V. Y. Razzhivin, "Zonation of Vegetation in the Russian Arctic,” In: I. Nordal and V. Y. Razzhivin, Eds., The Species Concept in the High North-A Panarctic Flora Initiative, The Norwegian Academy of Science and Letters, Oslo, 1999, pp. 113-130.

[28] M. K. Raynolds, D. A. Walker, C. A. Munger, C. M. Vonlanthen and A. N. Kade, "A Map Analysis of Patterned-Ground along a North American Arctic Transect," Journal of Geophysical Research, Vol. 113, No. G3, 2008, Article ID: G03S03. http://dx.doi.org/10.1029/2007JG000512

[29] D. A. Lipson, S. K. Schmidt and R. K. Monson, "Links between Microbial Population Dynamics and Nitrogen Availability in an Alpine Ecosystem,” Ecology, Vol. 80, No. 5, 1999, pp. 1623-1631. http://dx.doi.org/10.1890/0012-9658(1999)080[1623:LB MPDA]2.0.CO;2

[30] Q. Lin and P. C. Brookes, "An Evaluation of the Substrate-Induced Respiration Method,” Soil Biology and Biochemistry, Vol. 31, 1999, pp. 1969-1983. http://dx.doi.org/10.1016/S0038-0717(99)00120-0

[31] M. Zalamea and G. González, "Substrate-Induced Respiration in Puerto Rican Soils: Minimum Glucose Amendment,” Acta Científica, Vol. 21, No. 1-3, 2007, pp. 11-17.

[32] J. P. E. Anderson and K. H. Domsch, “A Physiological Method for the Quantitative Measurement of Microbial Biomass in Soils," Soil Biology and Biochemistry, Vol. 10, No. 3, 1978, pp. 215-221. http://dx.doi.org/10.1016/0038-0717(78)90099-8

[33] D. K. Button, F. Schut, P. Quang, R. Martin and B. Robertson, "Viability and Isolation of Marine Bacteria by Dilution Culture: Theory, Procedures, and Initial Results," Applied and Environmental Microbiology, Vol. 59, No. 3, 1993, pp. 881-891.

[34] S. A. Edlund and B. T. Alt, "Regional Congruence of Vegetation and Summer Climate Patterns in the Queen Elizabeth Islands, Northwest Territories, Canada," Arctic, Vol. 42, No. 1, 1989, pp. 3-23.

[35] A. E. Giblin, K. J. Nadelhoffer, G. R. Shaver, J. A. Laundre and A. J. McKerrow, "Biogeochemical Diversity along a Riverside Toposequence in Arctic Alaska,” Ecological Monographs, Vol. 61, No. 4, 1991, pp. 415-435. http://dx.doi.org/10.2307/2937049

[36] K. J. Nadelhoffer, A. E. Giblin, G. R. Shaver and J. A. Laundre, "Effects of Temperature and Substrate Quality on Element Mineralization in Six Arctic Soils,” Ecology, Vol. 72, No. 1, 1991, pp. 242-253. http://dx.doi.org/10.2307/1938918

[37] D. R. Zak and G. W. Kling, "Microbial Community Composition and Function across an Arctic Tundra Landscape,” Ecology, Vol. 87, No. 7, 2006, pp. 1659-1670. http://dx.doi.org/10.1890/0012-9658(2006)87[1659:MCC AFA]2.0.CO;2

[38] D. Elliot and J. Svoboda, "Microecosystem around a Large Erratic Boulder: A High-Arctic Study,” In: J. Svoboda and B. Freedman, Eds., Ecology of a Polar Oasis: Alexandra Fiord, Ellesmere Island, Canada, Captus, Toronto, 1994, pp. 207-213.

[39] G. Mueller, G. Broll and C. Tarnocai, "Biological Activity as Influenced by Microtopography in a Cryosolic Soil, Baffin Island, Canada,” Permafrost and Periglacial Processes, Vol. 10, No. 3, 1999, pp. 279-288. http://dx.doi.org/10.1002/(SICI)1099-1530(199907/09)10 :3<279::AID-PPP325>3.0.CO;2-A

[40] F. L. Bunnell, "Barrow, Alaska, USA,” In: P. Glowacki, and J. Bednarek, Eds., Structure and Function of Tundra Ecosystems, Ecological Bulletins No. 20, Swedish Natural Science Research Council, Stockholm, 1975, pp. 73124.

[41] N. Schmidt and M. Bölter, "Fungal and Bacterial Biomass in Tundra Soils Along an Arctic Transect from Taimyr Peninsula, Central Siberia,” Polar Biology, Vol. 25, No. 12, 2002, pp. 871-877.

[42] O. W. Heal, P. W. Flanagan, D. D. French and S. F. MacLean Jr., "Decomposition and Accumulation of Organic Matter,” In: L. C. Bliss, O. W. Heal and J. J. Moore, Eds., Tundra Ecosystems: A Comparative Analysis, Cambridge University Press, Cambridge, 1981, pp. 587-633.

[43] A. J. Holding, “The Microflora of Tundra,” In: L. C. Bliss, O. W. Heal and J. J. Moore, Eds., Tundra Ecosystems: A Comparative Analysis, Cambridge University Press, Cambridge, 1981, pp. 561-585. 